\title{
Faktor dan Dampak Nikah Paksa Terhadap Putusnya Pernikahan Menurut Kompilasi Hukum Islam
}

\author{
Hisdiyatul Izzah, Mir'atul Firdausi, Tiyan Iswahyuni \\ Institut Pesantren Sunan Drajat Lamongan, Institut Agama Islam Nahdlatul \\ Ulama Tuban \\ E-mail: izzahhisdiya@gmail.com, fiersmiror@gmail.com, \\ tiyaniswahyuni@gmail.com
}

\begin{abstract}
Abstrak: Tujuan pernikahan adalah untuk membangun keluarga yang sakinah, mawaddah dan warrohmah. Konsep tersebut sudah di terangkan dalam al-Quranul Karim. Guna terciptanya konsep tersebut maka, didalam rumah tangga harus didasari dengan rasa cinta dan kasih serta kepercayaan antara pasangan. Jadi disini, pernikahan yang terjadi itu harus atas dasar suka sama suka bukan adanya unsur keterpaksaan. Tetapi didalam praktiknya masih banyak sekali masyarakat yang memaksa anaknya atau keluarganya untuk melakukan perikahan tanpa dasar suka sama suka. Sehingga dalam mengarungi behtera rumah tangga akan mudah sekali goyah dan perceraian biasanya merupakan hal yang sering terjadi. Metode penelitian yang digunakan adalah field (penelitian lapangan) yaitu penelitian terjun langsung ke lapangan guna mengadakan penelitian pada objek yang dibahas yaitu faktor dan dampak nikah paksa terhadap putusnya perkawinan menurut kompilasi hukum islam. Hasilnya penelitian ini adalah; 1) ada tiga faktor yang melatar belakangi putusnya perkawinan; a) faktor ekonomi, b) faktor pendidikan, c) faktor sosial, 2) Dampak negatif pernikahan yang didasarkan oleh kawin paksa; a) Tidak Adanya Rasa Cinta Dan Kasih Sayang, b) Kurangnya rasa tanggung jawab terhadap keluarganya, c) Sering terjadi pertengkaran dalam keluarga.

Kata Kunci: Nikah paksa, percerain, hukum Islam.
\end{abstract}

\section{Pendahuluan}

Perjodohan merupakan hal yang biasa di lingkungan masyarakat kita. Praktik perjodohan bukan hanya dilakukan oleh kalangan masyarakat pedesaan saja, tetapi kalangan elit perkotaan juga melakukan hal tersebut. Kamus Besar Bahasa Indonesia mengartikan bahwa, dijodohkan (ejuduagih) lebih berarti dalam dua hal (orang, barang) dijadikan sebuah pasangan dan menjodohkan (ejuduagih) lebih berarti pada menjadikan dua hal (orang,barang) sebagai pasangan mengusahakan (menjadikan) 
bersuami isteri atau mengawinkan ${ }^{1}$. Islam menyebut perjodohan itu dengan istilah " khitbah".

Pernikahan merupakan sesuatu yang telah ditentukan oleh Allah SWT yang umum berlaku pada semua makhluk baik manusia, hewan, maupun tumbuh-tumbuhan. Allah SWT tidak berkehendak menjadikan manusia itu seperti makhluk lainnya yang hidup secara bebas mengikuti nalurinya dan berhubungan antara jantan dan betina secara anarki dan tanpa ada suatu aturan. Demi menjaga kehormatan dan kemuliaan manusia, Allah SWT menciptakan hukum sesuai dengan martabatnya. Sehingga hubungan laki-laki dan perempuan secara terhormat diatur melalui tata cara pernikahan.

Dalam Undang-undang pernikahan Nomor 1 Tahun 1974 Pasal 1 disebutkan bahwa "Pernikahan adalah ikatan lahir batin antara seorang pria dengan wanita sebagai suami isteri yang bertujuan membentuk keluarga (rumah tangga) yang bahagia dan kekal berdasarkan Ketuhanan Yang Maha Esa" 2 pernikahan adalah ikatan yang kuat dan sejati, yang mempersatukan perasaan, menjalin kehidupan bersama, menjadikan kehidupan suami isteri berjalan harmonis di atas kasih sayang, pernikahan adalah ikatan yang tepat untuk berbagi dan saling melimpahkan kasih sayang dengan segenap perasaan yang ada di antara kedua pasangan.

Adapun tujuan pernikahan adalah membentuk keluarga sakinah. Dengan terciptanya keluarga sakinah akan membawa terciptanya masyarakat yang baik. Keluarga yang bahagia juga akan berdampak baik bagi lingkungan masyarakat. Untuk menciptakan keluarga yang sejahtera, tentram, dan damai diperlukan persiapan yang matang sejak dini sebelum pernikahan sampai kepada berlangsungnya akad nikah. Karena itu pernikahan yang dipaksakan oleh orang tua atau nikah paksa sangat beresiko dan berakibat fatal terhadap pernikahan itu sendiri. Pada konsepnya pernikahan dilakukan untuk menciptakan kebahagiaan lahir bathin sehingga pernikahan harus berlandaskan suka sama suka, tanpa adanya paksaan dari pihak manapun. Oleh karena itu, jika sebuah proses perjodohan ini dilaksanakan, tidak menutup kemungkinn akan berimbas pada proses perceraian atau pelayanan gugat cerai yang dilakukan oleh

\footnotetext{
${ }^{1}$ Departemen Pendidikan Nasional, KBBI (Jakarta: PT Gramedia Pustaka Utama, 2008), hlm. 586

2 Pasal 1, Undang-undang pernikahan Nomor 1 Tahun 1974 Tentang Perkawinan
} 
pihak suami maupun isteri yang dipaksa menikah.

Secara Yuridis-Formal, didalam Peraturan Pemerintah (PP) Nomer 9 Tahun 1975 pasal 19 jo Kompilasi Hukum Islam diatur tentang alasanalasan perceraian yang dibenarkan oleh Hukum di Indonesia. Adapun alasan-alasan perceraian tersebut adalah:

1. Salah satu pihak berbuat zina atau pemabuk, penjudi, dan lain sebagainya yang sukar disembuhkan.

2. Salah satu pihak meninggalkan pihak lain selama 2 (dua) tahun berturut-turut tanpa izin pihak lain dan tanpa alasan yang sah atau karena hal lain di luar kemampuannya.

3. Salah satu pihak mendapat hukuman penjara 5 (lima) tahun atau hukuman yang lebih berat setelah pernikahan berlangsung.

4. Salah satu pihak melakukan kekejaman atau penganiayaan berat yang membahayakan pihak lain.

5. Salah satu pihak cacat badan atau penyakit dengan akibat-akibat tidak dapat menjalankan kewajibannya sebagai suami/isteri.

6. Antara suami dan isteri terus menerus menjadi perselisihan dan pertengkaran serta tidak ada harapan akan hidup rukun lagi dalam rumah tangga ${ }^{3}$.

Jika melihat alasan-alasan perceraian dalam PP Nomer 9 Tahun 1975

Pasal 19 Jo Kompilasi Hukum Islam di atas, maka perceraian karena alasan nikah paksa belum masuk dalam PP tersebut, begitu juga dalam peraturan positif yang lain.

Pandangan yuridis memang membutuhkan interpretasi. Pandangan yuridis juga hanya berdiri sebagai norma umum (common sense), sedangkan interpretasi sosial-kebudayaan ada pada aspek pendekatan sosiologis. Erna Karim mengatakan bahwa setidaknya ada lima (5) varian penyebab perceraian; pertama gagalnya membangun komunikasi yang baik. Kedua, perselingkuhan dan tidak setia terhadap pasangan. Ketiga, kekerasa dalam rumah tangga. Keempat, persoalan ekonomi. Keempat, pernikahan dini ${ }^{4}$.

Bila pernikahan dengan paksaan tidak ada rasa cinta dan kasih sayang, di mana rasa cita dan kasih sayang sebagai pondasi dasar dalam kehidupan rumah tangga agar tercipta ikatan lahir dan bathin diantara

\footnotetext{
${ }^{3}$ Sudarsono, Hukum Perkawinan Nasional, (Jakarta: Rieka Cipta, 1994), hlm. 308

4 Erna Karim, Pendekatan Perceraian dari Prespektif Sosiologi, Dalam Ihromi, Bunga Rampai Sosiologi Keluarga, (Jakarta: Yayasan Obor Indonesia,1999), hlm. 135
} 
keduanya. Jika hal tersebut tidak ada dalam salah satu pihak atau bahkan tidak ada diantara keduanya, maka akan menimbulkan persoalan dalam kehidupan pasangan tersebut. Sehingga nikah paksa pada umumnya identik dengan istilah pernikahan tanpa dasar cinta yang tentunya dalam mengarungi behtera rumah tangga akan mudah sekali goyah dan perceraian biasanya merupakan hal yang sering terjadi.

\section{Metode Penelitian}

Dalam penelitian ini jenis penelitian yang digunakan adalah penelitian field (penelitian lapangan) yaitu penelitian terjun langsung ke lapangan guna mengadakan penelitian pada objek yang dibahas yaitu faktor dan dampak nikah paksa terhadap putusnya perkawinan menurut kompilasi hukum islam (studi kasus di Desa Karang Wedoro Kecamatan Turi Kabupaten Lamongan)., selain itu penelitian ini termasuk penelitian kualitatif karena penelitian ini bertujuan untuk mengungkapkan fakta secara menyeluruh melalui pengumpulan data di lapangan dan memanfaatkan diri peneliti sebagai instrument.

\section{Pengertian Nikah Paksa}

Sedangkan pengertian "paksa" menurut kamus besar bahasa Indonesia adalah mengerjakan sesuatu yang diharuskan walaupun tidak $\mathrm{mau}^{5}$. Menurut istilah adalah perbuatan yang dilakukan tanpa ada kerelaan diantara pihak. Kata nikah paksa juga dikenal dengan istilah nikah ijbar, sedangkan nikah ijbar berawal dari kata ajbara-yujbiru ijbaaran. Mengenai nikah paksa (ijbar) itu sendiri memiliki arti pernikahan yang dilakukan dengan cara pemaksaan atau mengawinkan seseorang dengan cara pemaksaan dan keras tidak ada kerelaan diantara dua pihak.

\section{Macam-macam Nikah Paksa}

1. Nikah paksa terhadap janda

Wali adalah orang yang mengurus akad pernikahan seorang perempuan dan tidak membiarkannya melakukan akad sendiri tanpa wali. Dan tidak ada paksaan dalam penikahan . Menurut kesepakatan bersama kaum muslimin, janda yang udah baligh tidak boleh dinikahkan tanpa seizinnya, baik oleh ayahnya maupun (wali) yang lain 6.

5 Departemen Pendidikan Nasional, KBBI..... hlm. 1002

${ }^{6}$ Abu Malik Kamal bin Ass-Sayyid Salim, Fiqih Sunnah Wanita, (Jakarta: Raja Grafindo, 2012), hlm. 215 
2. Nikah paksa terhadap perawan yang sudah baligh (dewasa)

Terkait setatus perawan yang sudah baligh, apakah walinya mempunyai hak untuk mengawinkannya secara paksa atau tidak? Penadapat ulama' dibagi menjadi dua, dan yang paling shahih ia disamakan seperti janda, sehingga wali tidak berhak mengawinkannya secara paksa. Ini adalah pendapat Abu Hanifah dan murid muridnya, dan pendapat ahmad dalam sebuah riwayatnya, Ahmad dan Ishaq berpendapat bahwa seorang wali boleh menikahkan anak gadisnya yang perawan tanpa meminta izin darinya. Imam Syafi'i menilai meminta persetujuan seorang gadis bukan perintah wajib. Sehingga pernikahan gadis yang dipaksakan tanpa izinnya sah sah saja. Sebab jika sang ayah tidak dapat menikahkan tanpa izin si gadis, maka seakan akan gadis tidak ada bedanya dengan janda?.

3. Nikah paksa terhadap perawan yang belum baligh (masih belia)

Para ulama selain segelintir kalangan yang berpendapat, sepakat bahwa gadis belia yang belum baligh boleh dinikahkan paksa oleh ayahnya atau wali yang berada dibawah perwaliannya tanpa keharusan meminta izinnya. sebab tidak ada gunanya meminta izin pada orang tidak mengerti apa itu izin serta pada orang yang sama saja sikap diamnya dan keengganannya ${ }^{8}$.

Pertimbangan lain. Menurut ketentuan nash dan ijma' usia belia (belum baligh) merupakan alasan untuk mencegah umuk melakukan suatu yang legal. Sehingga ia pun boleh dipaksa. Namun, jika gadis belia ini bisa memahami pernikahan dan hakikatnya. maka pendapat yang kuat mengharuskan permintaan izinnya lerlebih dahulu sebelum mengawinkannya, karena ia sudah termasuk katagori umum "perawan" ditambah adanya kemaslahatan tersendiri jika meminta izinnya.

\section{Faktor-Faktor Nikah Paksa}

Kawin paksa hingga saat ini masih saja diperdebatkan, hal ini disebabkan oleh kekeliruan penempatan hak dan kewajiban yang dapat dijadikan sebagai faktor utama munculnya kawin paksa, antara lain;

a) Kekeliruan dalam menempatkan hak dan kewajiban orang tua terhadap anak dan anak terhadap orang tuanya yang mana sering kali

7 Abu Malik Kamal bin Ass-Sayyid Salim, Fiqih Sunnah Wanita, hlm. 281

${ }^{8}$ Abu Malik Kamal bin ass-Sayyid Salim, hlm. 222 
rancu dalam penerapannya sehingga hak kadang dijadikan sebagai kewajiban dan kewajiban dijadikan sebagai hak bahkan kadang pula menuntut akan kewajiban, lupa dan tidak menghiraukan akan hakhak orang lain dan sebaliknya.

b) Restu dijadikan sebagai kewajiban mutlak orang tua dalam menentukan pasangan anaknya.

c) Adanya pemikiran bahwa orang tua hanya akan memberikan yang terbaik bagi anaknya, dan tak akan pernah melihat anaknya terlantar maupun disakiti oleh orang lain yang membuat mereka terlalu memaksakan kehendak mereka sendiri tanpa menghiraukan perasaan anaknya yang tanpa sadar mereka telah dengan tidak sengaja melukai dan menyakiti hati anaknya.

d) Nilai dan norma juga merupakan faktor penyebab adanya kawin paksa. Baik agama sebagai sebuah keyakinan maupun budaya yang masih kokoh. Seperti kewajiban orang tua untuk mencarikan pasangan hidup sang anak, begitu juga dengan stigma terhadap perempuan yang tidak laku, telah mendorong orang tua untuk mencarikan sekuat tenaga teman hidupnya.

e) Adannya kebiasaan atau tradisi menjodohkan anak, seperti halnya di lingkungan pesantren, antara kiyai satu dengan yang lainnya saling menjodohkan anaknya. yang menyebabkan anak enggan menolak demi menghormati agamanya9 .

\section{Dampak Negatif Nikah Paksa}

Tidak ada cinta, jika dari awal tidak ada cinta, bisa jadi setelah menikah tetap tidak ada cinta diantara kedua orang yang dijodohkan tersebut:

1) Yang sewaktu pacaran saling cinta saja bisa jadi musuhan setelah menikah apalagi yang dari awal ada rasa benci setengah mati karena dipaksa kawin.

2) Kehilangan gairah hidup, jika sudah tidak ada cinta dalam hidup, bisa membuat orang malas menjalani hidup. Apalagi jika ditambah pasangan punya banyak keburukan yang tidak mau diperbaiki, ekonomi sulit, keluarga pasangan tidak baik lingkungan masyarakat sekitar kurang baik dan lain-lain. Jika sudah begitu, maka bisa

\footnotetext{
9 http://cinta.organisasi.org/1970/01/efek-dampak-buruk-perjodohan-nikah-kawinpaksa-seperti-siti-nurbaya.html?m=1
} 
membuat seseorang jadi temperamental, malas-malasn, dengki dan lain sebagainya.

3) Kurang peduli keluarganya, menikah karena terpaksa akibat dijodohkan paksa bisa membuat seseorang jadi kurang peduli dan kurang mencintai keluarganya suami atau isteri bisa diajukan dan bahkan anak-anak oun bisa juga tidak dipedulikan karena tidak adanya rasa cinta dari awal menikah dn kebencian terhadap pernikahan paksa yang dijalaninya dengan penuh kepura-puraan.

4) Memicu perselingkuhan, yang bahaya adalah jika setelah menikah satu ataupu dua belah pihak mencari cinta yang lain yang lebih sejati dan tanpa kepura-puraan. Bisa jadi aka nada jalinan kasih kembali dengan mantan pacar atau pria / wanita lain yang baru dicintainya.

5) Bisa menimbulkan konflik dan ujungnya cerai, apabila sudah tidak ada gairah dalam menjalani rumah tangga, tidak ada cinta, tidak peduli terhadp suami atau anak selingkuh, sering berselisih dengan anggota kleluarga, terjadi kekerasan fisik dan lain-lain, maka bisa menjadi boomerang yang berujung pada perceraian.

6) Dapat menganggu (psikis) kejiwaan seorang isteri ${ }^{10}$.

\section{Tinjauan Umum Tentang Putusnya Pernikahan}

Dalam Undang-undang pernikahan Nomor 1 Tahun 1974 pada BAB VIII tentang putusnya pernikahan serta akibatnya Pasal 38. Pernikahan dapat diputus karena tiga hal yaitu karena kematian, perceraian dan keputusan pengadilan. Dalam hal ini penulis memfokuskan pembahasan putusnya pernikahan karena perceraian.

Perceraian merupakan bagian dari perikahan, sebab tidak ada perceraian tanpa diawali penikahan terlebih dahulu. Penikahan merupakan awal dari hidup bersama antara seorang wanita yang diatur dalam peraturan perundang undangan yang berlaku. Dalam hal ini. pernikahan selalu dipandang sebagai dasar bagi unit keluarga yang mempunyai arti penting bagi penjagaan moral atau akhlak masyarakat dan pembentukan peradaban ${ }^{11}$.

Allah Swt. telah menetapkan dalam Al Quran bahwa kedua pasangan suami isteri harus segera melakukan antisipasi apabila tiba tiba timbul gejala-gejala dapat diduga akan menimbulkan gangguan kehidupan

10 http://cinta.organisasi.org/1970/01/efek-dampak-buruk-perjodohan-nikah-kawinpaksa-seperti-siti-nurbaya.html?m=1

${ }^{11}$ Rifyal Ka'bah, Permasalahan Pernikahan Dalam Majalah Varian Peradilan No. 271 juni 2008, (Jakarta: IKAHI, 2008), hlm. 7 
rumah tangganya, yaitu dalam firman Allah Swt. dalam surat An-Nisa ayat 34;

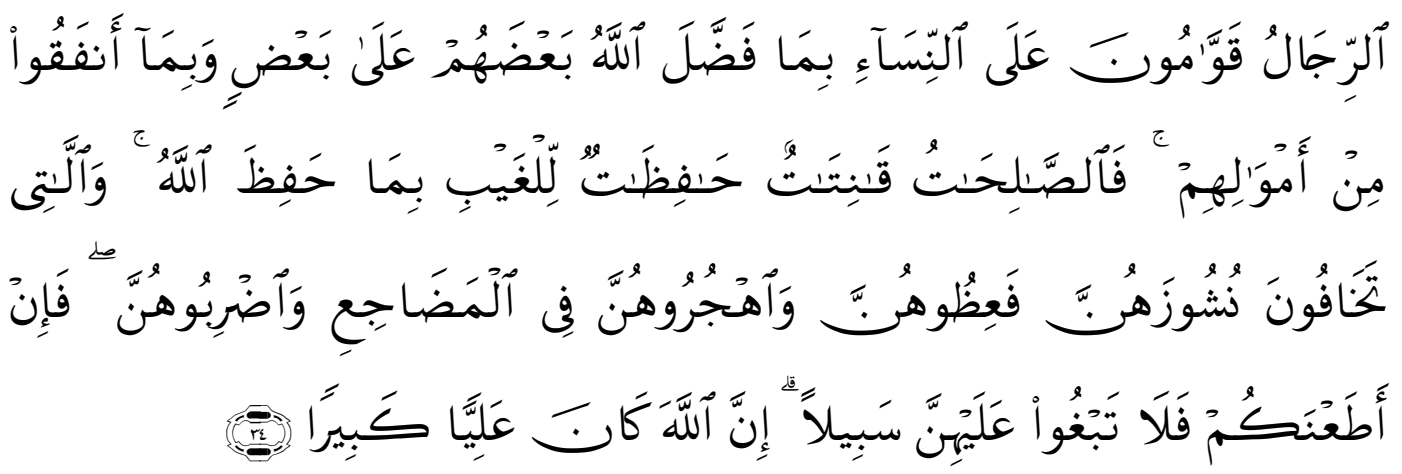

Kaum laki-laki itu adalah pelindung bagi kaum wanita, oleh karena Allah telah melebihkan sebahagian mereka (laki-laki) atas sebahagian yang lain (wanita), dan karena mereka (laki-laki) telah menafkahkan sebagian dari harta mereka. sebab itu Maka wanita yang saleh, ialah yang taat kepada Allah lagi memelihara diri ketika suaminya tidak ada, oleh karena Allah telah memelihara (mereka). wanita-wanita yang kamu khawatirkan nusyuznya, Maka nasehatilah mereka dan pisahkanlah mereka di tempat tidur mereka, dan pukullah mereka. kemudian jika mereka mentaatimu, Maka janganlah kamu mencaricari jalan untuk menyusahkannya. Sesungguhnya Allah Maha Tinggi lagi Maha besar.

Pengertian perceraian yang dijelaskan secara tegas dalam Pasal 117 KHI yang menyebutkan bahwa perceraian adalah ikrar suami dihadapkan sidang Pengadilan Agama yang menjadi salah satu sebab putusnya pernikahan ${ }^{12}$. Berdasarkan uraian tersebut dapat diperoleh pemahaman bahwa perceraian adalah putusnya ikatan pernikahan antara suami isleri yang sah dengan menggunakan lafadz talak atau semisalnya, selanjulnya dipertegas oleh ketentuan Pasal 38 Undang-undang Nomor. 1 Tahun 1974 tentang Pernikahan, bahwa pernikahan dapat putus disebabkan karena kematian, perceraian dan putusan pengadilan, yang mana akibat hukum yang ditimbulkan dari ketiga sebab tersebut berbeda beda. Sedangkan menurut hukum Islam talak berarti:

a. Menghilangkan ikatan pernikahan atau mengurai keterikatan dengan ucapan tenentu.

b. Melepaskan ikatan pcrnikahan dan mengakhiri hubungan suami isteri.

12 Kompilasi Hukum Islam, hlm. 36 
c. Melepaskan ikatan akad pernikahan dengan ucapan talak atau yang sepadan dengannya ${ }^{13}$.

\section{Hukum Talak atau Perceraian}

Ibnu Hajar al-Asqani mengatakan bahwa hukum talak bermacammacam yaitu haram, makruh, wajib, sunnah, dan boleh. Adapun uraian yang selengkapnya adalah sebagai berikut ${ }^{14}$.

1) Haram: talak yang diharamkan ialah yang termasuk talak bid'i (bid'ah) dan memiliki beberapa bentuk.

2) Makruh: talak yang dimakruhkan adalah talak yang tidk mempunyai sebab, dan pernikahannya masih memungkinkan untuk diteruskan.

3) wajib: talak yang diwajibkan adalah talak dikarenaka adanya perpecahan (tidak mungkin untuk bersatu kembali).

4) Sunnah: talak yang disunnahkan adalah talak yang disebabkan si isteri tidak memiliki sifat afifah (menjaga kehormatan diri) dan tidak lagi memperhatikan perkara-perkarayang wajib dalam agama (seperti tidak memperhatikan shalat lima waktu), serta sulit diperingatkan.

5) Boleh: tidak diperbolehkan apabila suami isteri memiliki tingkah laku, akhlak yang buruk, serta dapat berdampak negatif jika keduanya terus bersama. ${ }^{15}$

\section{Analisis}

Dalam Kompilasi Hukum Islam tidak dijelaskan secara rinci tentang hal-hal yang menjadikan pernikahan itu putus melainkan hanya disebutkan 3 inti saja, akan tetapi dalam Kompilasi Hukum Islam menyebutkan syarat dan ketentuan seseorang dapat melangsungkan pernikahan seperti yang disebutkan dalam Kompilasi Hukum Islam tentang syarat-syarat perkawinan dalam Pasal 16 dan Pasal 17 bahwa:

Pasal $16^{16}$

(1) Perkawinan didasarkan atas persetujuan calon mempelai.

(2) Bentuk persetujuan calon mempelai wanita, dapat berupa pernyataan tegas dan nyata dengan tulisan, lisan atau isyarat tapi dapat juga berupa diam dalam arti selama tidak ada penolakan yang tegas.

\footnotetext{
${ }^{13}$ Zahri Hamid, Pokok-Pokok Hukum Pernikahan Islam dan Undang-undang Pernikahan Indonesia, (Yogyakarta: Bina Cipta. 1976), hlm. 73

${ }^{14}$ Atiqah Hamid, Fiqih Wanita, (Diva Press: 2016). Hlm. 119

${ }^{15}$ Atiqah Hamid, hlm. 120

${ }^{16}$ Kompilasi Hukum Islam, hlm. 6
} 
Pasal 1717

(1) Sebelum berlangsungnya perkawinan Pegawai Pencatat Nikah menanyakan lebih dahulu persetujuan calon mempelai dihadapan dua saksi nikah.

(2) Bila ternyata perkawinan tidak disetujui oleh salah seorang calon mempelai maka perkawinan itu tidak dapat dilangsungkan.

(3) Bagi calon mempelai yang menderita tuna wicara atau tuna rungu persetujuan dapat dinyatakan dengan tulisan atau isyarat yang dapat dimengerti.

Dilihat dari syarat-syarat yang telah di sebutkan dalam Kompilasi Hukum Islam di atas maka pernikahan yang telah dilaksanakan dan telah sah secara hukum itu tidak ada yang namanya paksaan karena dalam pasal 16 ayat (1) dan Pasal 17 ayat (1) Kompilasi Hukum Islam telah disebutkan bahwa pernikahan harus didasari oleh persetujuan kedua calon. Maka secara tidak langsung ketika sudah sah maka syarat itu berlaku sebagai pertimbangan ketika akan terjadi perceraian. Lantas bagaimana ketika ada seseorang yang mengajukan perceraian dengan alasan mereka dulu menikah karena dipaksa (jodohkan) oleh orang tuanya, apakah permohonan/gugatan tersebut dapat diterima? tidak, akan tetapi yang diterima dan dipertimbangkan untuk dikabulkan adalah faktor-faktor yang menjadikannya mengajukan gugatan cerai.

Sedangkan putusnya perkawinan adalah hasil akhir dari suatu masalah yang tak mampu terselesaikan secara kekeluargaan hingga akhirnya kedua belah pihak antara suami dan isteri setuju untuk melangsungkan perceraian. Dalam Kompilasi Hukum Islam pasal 38, ada tiga hal yang menyebabkan putusnya perkawinan:

1. Kematian

2. Perceraian

3. Atas keputusan pengadilan ${ }^{18}$.

Dari sini lah peneliti lebih menekankan untuk membahas putusnya perkawinan karena perceraian. Melihat dari kalimat di atas bahwa perceraian adalah keputusan akhir maka dapat dikatakan bahwa selama pasangan tersebut menjalani kehidupan setelah pernikahan keduanya pernah atau bahkan sering mendapatkan perlakuan tidak baik selama masa pernikahannya sampai mendapat tekanan yang sangat kuat baik jasmani atau rohani hingga akhirnya memutuskan untuk berpisah.

${ }^{17}$ Kompilasi Hukum Islam, hlm. 6

${ }^{18}$ Kompilasi Hukum Islam, hlm. 35 
Dalam hal ini peneliti akan membahas terkait faktor-faktor yang menjadikan orang tua untuk melangsungkan pernikahan anaknya serta dampak dari pernikahan tersebut.

Di dalam Kompilasi Hukum Islam tidak ada penyebutan terkait halhal yang menjadikannya pernikahan itu terlaksana melainkan hanya tercantum dasar, syarat-syarat, pencegahan, batal, perjanjian, putus dan akibat perkawinan. Namun peneliti telah mengambil data dari data sekunder yang menyebabkan orang tua hendak melangsungkan pernikahan anaknya dengan cara paksaan antara lain :

1. Faktor yang melatarbelakangi orang tua melaksanakan nikah paksa:

Peneliti disini hanya menguraikan 3 faktor yang banyak terjadi di Desa Karang Wedoro Kecamatan Turi Kabupaten Lamongan.

a. Faktor ekonomi

Ekonomi adalah penyebab yang paling berpengaruh dalam kasus perceraian, karena dalam menjalankan sebuah keluarga pastilah terdapat kebutuhan yang menyangkut uang baik untuk biaya makan sehari-hari ataupun untuk pembiayaan pendidikan anaknya, hal ini telah di sebutkan dalam KHI pasal 80 ayat 4 tentang kewajiban seorang suami yaitu "sesuai dengan penghasilannya suami menanggung: a) nafkah, kiswah dan tempat kediaman bagi istri; b) biaya rumah tangga, biaya perawatan dan biaya pengobatan bagi istri dan anak; c) biaya pendidikan bagi anaknya".

Di katakan bahwa jika sang suami tidak mampu untuk menjalankan tugasnya sebagai seorang suami maka sang istri berhak untuk menagih bahkan bisa mengajukan cerai jika istri terabaikan hingga 2 tahun berturut-turut tanpa adanya kejelasan dari sang suami seperti yang tertera dalam KHI pasal 116 ayat $b$ "salah satu pihak meninggalkan pihak lain selama 2 (dua) tahun berturut-turut tanpa izin pihak lain dan tanpa alasan yang sah atau karena hal lain diluar kemampuannya" 19 .

Dari sini dapat di simpulkan bahwa pentingnya ekonomi dalam sebuah keluarga dapat membawa keluarga menjadi sakinah rukun dan sebaliknya yang berujung pada perceraian. Standar ekonomi masyarakat Desa Karang Wedoro mayoritas masih dibawah mampu, serta keterbatasan SDM membuat

${ }^{19}$ Kompilasi Hukum Islam, hlm. 36 
masyarakat sulit mendapatkan pekerjaan. Maka dari itu dalam hal pernikahan orang tua sering berpikir bahwa anaknya dapat bahagia jika perekonomian kelak seimbang atau bahkan melimpah, hal ini di buktikan dengan hasil wawancara dengan bapak Abdul Salam yang mengatakan bahwa ${ }^{20}$ :

"begini mbak, anak saya, saya nikahkan secara paksa soalnya emang harta itu perlu, karena saya juga mencontoh sesuai hadits kanjeng nabi, kalau harta itu yang paling utama, setelah itu baru kedudukan statusnya, kecantikanya, dan baru Agamanya".

Seperti yang telah di katakan oleh bapak abdul salam bahwa beliau menikahkan anaknya berdasarkan ajaran rosulullah yang sabdanya nikahlah karena hartanya, nasabnya, parasnya dan agamanya oleh karena itu bapak abdul salam menikahkan anaknya dengan orang yang memiliki banyak harta agar anaknya bahagia kedepannya. Ungkapan ini juga di perkuat dengan pendapat dari Ibu Alfiyah dalam wawancaranya yang mengatakan bahwa: 21

“orang tua melakukan nikah paksa terhadap anaknya tentu mempunyai beberapa alasan salah satunya yang paling berpengaruh yaitu ekonomi, semua orang tua ingin anaknya hidup dengan mempunyai banyak uang, karena zaman juga semakin modern, gaya hidup sekarang dengan dulu tentu sudah berbanding jauh, dari situ semua orang tua pasti mempunyai fikiran yang sama untuk memilihkan pasangan yang dianggap lebih mampu untuk mencukupi kebutuhan anaknya".

Ibu alfiyah memandang bahwa uang bukan untuk dirinya, melainkan untuk anaknya di masa mendatang, karena zaman semakin modern dan sudah menjadi hukum alam bahwa kita tidak bisa menentang kemajuan zaman dan hanya bisa mengikutinya.

Peneliti menyadari bahwa setiap orang mempunyai sebab atau alasan yang berbeda-beda dalam menjalankan suatu keluarga yang didasari atas nikah paksa. Selain itu data juga diperoleh dari Bapak

\footnotetext{
${ }^{20}$ Bapak Abdul Salam selaku Orang Tua dari pelaku Nikah Paksa sekaligus Moden Desa Karang Wedoro Kecamatan Turi Kabupaten Lamongan

${ }^{21}$ Hasil wawancara dengan Ibu Alfiyah selaku Orang Tua dari pelaku Nikah Paksa.
} 
Juniman 22:

“ekonomi jelas sangat penting, bahkan yang paling utama, orang tidak mempunyai uang yang banyak maka tidak akan bisa hidup bahagia, hidup semua serba uang, mau apa2 semuanya butuh uang, kalau orang mempunyai uang banyak ingin beli ini itu bisa terwujud, itu alasan saya untuk menikahkan paksa dengan orang yang lebih mampu"

Dari semua pernyataan diatas maka peneliti juga ingin menyampaikan bahwasanya pernyataan tersebut benar, dan sesuai dengan apa yang diceritakan oleh narasumber, peneliti juga mendapatkan informasi dari salah seorang warga bahwa keluarga tersebut termasuk keluarga menengah atas dan dari kedua keluarga tersebut tidak ingin hartanya jatuh ditangan orang lain, maka dari itu kedua keluarga tersebut mempunyai keinginan untuk menikahkan paksa anaknya, dengan alasan mereka ingin hartanya tetap berada dalam lingkup keluarganya.

Melihat dari beberapa pernyataan diatas, maka dapat disimpulkan bahwasanya faktor ekonomi sangat berpengaruh bagi pernikahan tersebut, ekonomi merupakan kebutuhan paling pokok untuk keberlangsungan hidup.

Tetapi sesungguhnya pernikahan tidak harus didasarkan pada perekonomian, harta memang penting tetapi seharusnya tidak diletakkan yang paling utama, karena segala sesuatu di bumi ini sifatnya sementara dan masalah rizki sangat jelas, seperti yang telah dijelaskan dalam Surat At-Talaq ayat (3) yang menyatakan bahwa Allah memberikan rezeki dari arah yang tidak disangka-sangka.

b. Faktor pendidikan

Pendidikan adalah suatu hal yang dianggap penting dalam kehidupan manusia, pasalnya sampai saat ini pendidikan dipandang sebagai salah satu unsur kemajuan negara. Tidak bisa dianggap sebagai negara maju jika aspek pendidikan tidak diperhatikan. Bahkan dalam KHI di jelaskan tentang keharusan untuk memberikan pelajaran/ pendidikan kepada seorang istri dan anaknya, seprti dalam pasal 80 ayat $3 \mathrm{KHI}$ "Suami wajib memberikan pendidikan agama kepada istrinya dan memberinya kesempatan belajar pengetahuan yang berguna dan bermanfaat

${ }^{22}$ Hasil wawancara dengan Bapak Juniman selaku Orang Tua dari pelaku Nikah Paksa. 
bgi agama, nusa dan bangsa". ${ }^{23}$ Maka dari itu masyarakat Desa Karang Wedoro kecamatan Turi Kabupaten Lamongan beranggapan bahwa orang yang mengenyam pendidikan tinggi akan menjamin kesejahteraan kehidupan seseorang, berikut ungkapan dari Ibu Tutik 24 :

"selain faktor ekonomi, faktor pendidikan juga berpengaruh, orang mempunyai pendidikan yang tinggi biasanya juga mempunyai pekerjaan yang layak pula, beda dengan orang yang tidak mempunyai pendidikan, mencari pekerjaan saja pun susah, andaikan dapat pekerjaan paling-paling jadi kuli bangunan, jadi pendidikan juga berpengaruh".

Selain itu, berikut pernyataan dari bapak Hariyono ${ }^{25}$ :

“saya tidak mau kalau anak saya menikah dengan orang yang tidak berpendidikan, pendidikan sangat penting untuk mencari pekerjaan, orang tidak mempunyai pendidikan akan sulit mendapatkan pekerjaan, kalau mencari pekerjaan saja sulit bagaimana bisa mencukupi kebutuhan anak saya?, begitu ujarnya.

Peneliti kurang setuju dengan pernyataan dari Bapak Hariono, dari yang peneliti ketahui keluarga tersebut tidak ada yang berpendidikan. Karena sejauh yang peneliti ketahui adalah pendidikan sangat di perlukan bukan hanya untuk mencari pekerjaan melainkan untuk menjunjung tinggi martabat keluarganya dan agar supaya keluarga tersebut dapat hidup rukun karena saling memberikan nasihat dan pembelajaran. Hal ini selaras dengan pasal 77 ayat 3 dan 4 ) suami istri memikul kewajiban untuk mengasuh dan memelihara anak-anak mereka, baik mengenai pertumbuhan jasmani, rohani maupun kecerdasannya dan pendidikan agamanya; 4) suami istri wajib memelihara kehormatannya"26. Dari apa yang telah di sebutkan dapat di katakan bahwa pendidikan penting bukan hanya untuk suami akan tetapi istri juga ikut menanggung beban pendidikan untuk mencerdaskan anaknya.

c. Strata sosial

Dalam hal strata sosial KHI tidak menjelaskan dengan rinci karena hal ini tidak menyangkut hukum personal ataupun hukum

${ }^{23}$ Kompilasi Hukum Islam, hlm. 25

24 Hasil wawancara dengan Ibu Tutik selaku Orang Tua dari pelaku Nikah Paksa.

${ }^{25}$ Hasil wawancara dengan Bapak Hariyono selaku Orang Tua dari pelaku Nikah Paksa.

${ }^{26}$ Kompilasi Hukum Islam, hlm. 24 
pada umumnya melainkan hal ini merujuk kepada hukum adat atau kebiasaan masyarakat sekitar yang ana telah terbiasa dengan menjodohkan anak kyai dengan sesama anak kyainya misalnya. Sedangkan Orang tua kadang mempunyai gengsi yang tinggi, mereka ingin anaknya mempunyai pasangan yang berkedudukan atau berpangkat dengan harapan supaya anak dan keluarganya juga ikut terpandang tinggi derajatnya di mata masyarakat. Seperti yang telah dikatakan Ibu Tutik ${ }^{27}$ :

"ya mau gimana lagi kita ini orang yang hidupnya pas, sedangkan ada orang yang berniat menikahi anak saya dan kebetulan orang itu terkenal dihormati dan terpandang di desanya. ya dengan harapan semoga derajat anak saya juga akan terangkat dan dihormati di masyarakat".

Selain itu terkadang orang tua dari dulunya sudah membuat kesepakatan bahwa ada rencana untuk menikahkan anaknya karena kedua orang tua tersebut mempunyai kesetaraan dalam strata sosial dan tidak mau menikahkan anaknya dengan seorang yang lebih rendah strata sosial keluarganya, seperti pernyataan yang telah disampaikan oleh bapak Abdul Salam ${ }^{28}$ :

"saya dan besan saya dulu sudah sejak lama mempunyai komitmen untuk menikahkan anak kami, karena kami tidak mau anak kami menikah dengan orang yang dipandang rendah di masyarakat.

Dari pernyataan Bapak Abdul Salam tesebut peneliti kurang setuju dengan adanya perjanjian dengan calon besannya tersebut, karena anak mempunyai hak untuk memilih calon pasangan, karena pada nantinya yang menjalani hubungan anaknya bukan orang tuanya, apabila pernikahan tersebut karena paksaan orang tuanya banyak kemungkinan anak tersebut tidak sakinah mawaddah warahma, berarti pernikahan tersebut tidak sesuai dengan KHI pasal 4 perkawinan bertujuan untuk mewujudkan kehidupan rumah tangga yang sakinah, mawaddah, dan rahmah.

2. Dampak Negatif Pernikahan yang didasarkan oleh Kawin Paksa.

a. Tidak adanya rasa cinta dan kasih sayang.

Pernikahan memang harus didasari rasa cinta dan kasih sayang, demi terciptanya keluarga yang bahagia dan harmonis,

27 Ibu Tutik, Tanggal 30 Juli 2018.

${ }^{28}$ Bapak Abdul Salam, Tanggal 30 Juli 2018. 
apabila pernikahan tersebut tidak mempunyai dasar cinta apalagi sayang maka sulit untuk terwujudnya keluarga yang bahagia. Dalam Kompilasi Hukum Islam Pasal 77 ayat (2) menyebutkan: suami isteri wajib saling cinta mencintai, hormat menghormati, setia dan memberi bantuan lahir bathin yang satu kepada yang lain ${ }^{29}$. Dan sudah sangat jelas dalam pasal tersebut wajib mengatakan saling cinta mencintai, apabila pernikahan tersebut tidak mempunyai dasar cinta maka tidak sesuai dengan apa yang ada dalam Kompilasi Hukum Islam Pasal 77 Ayat (2). Hal tersebut juga dipaparkan oleh Bapak Moh Ra'I dari hasil wawancara dengan penilis ${ }^{30}$ :

"menurut saya, seseorang menikah haruslah kenal terlebih dahulu dengan pasangannya, agar tercipta keluarga yang harmonis, karena menikah merupakah hal yang sangat serius, seseorang menikah harus mengerti karakter pasangannya, jika tidak mengerti karakter pasangannya, dan tidak mempunyai rasa cinta dan kasih sayang khawatir setelah menikah menimbulkan perselisihan dan banyak masalah".

Hal tersebut juga diperkuat dengan hasil wawancara dengan Bapak Sutrisno ${ }^{31}$ :

"saya kurang setuju dengan adanya nikah paksa, karena orang nikah dipaksa jelas tidak mempunya rasa cinta dan kasih sayang terhadap pasangannya, kalu rasa cinta dan kasih tidak ada dalam pasangan tersebut bagaimana keluarga itu bisa harmonis? Mustahil sekali jika mereka beranggapan keluarganya akan baik-baik saja, saya yakin jelas setiap hari menimbulkan permasalahan."

Dari hasil wawancara dengan narasumber di atas peneliti sependapat bahwa rasa saling mecintai dan kasih sayang sangat dibutuhkan dalam perkawinan karena fondasi dasar keluarga sakinah adalah adanya cinta dan kasih sayang diantara pasangan. Sehingga mampu memberikan hal yang sama kepada anggota keluarga yang lain.

${ }^{29}$ Kompilasi Hukum Islam, hlm. 2

${ }^{30}$ Kompilasi Hukum Islam, 24

31 Hasil wawancara dengan Bapak Sutrisno selaku Tokoh Masyarakat Desa Karang Wedoro. 
b. Kurangnya rasa tanggung jawab terhadap keluarganya.

Seseorang yang sudah menikah tanggung jawabnya semakin besar, harus siap lahir bathin, apalagi kalau sudah mempunyai anak, ketika pernikahan tersebut terjadi bukan karena kehendak anak maka anak tersebut kurang bisa bertanggungjawab terhadap pernikahanya, padahal dalam Kompilasi Hukum Islam Pasal 77 ayat (3) disebutkan: suami isteri memikul kewajiban untuk mengasuh dan memelihara anak-anak mereka, baik mengenai pertumbuhan jasmani, rohani maupun kecerdasanya ${ }^{32}$. seperti halnya yang telah di sampaikan oleh bapak Moh ra'i 33:

“Dari beberapa kasus yang telah terjadi seorang yang menikah atas dasar paksaan menurut saya mereka kurang bertanggung jawab terhadap pernikahanya seperti contoh keluarga Bapak Andik dan Ibu Heli Susanti, Bapak andik kurang bertanggung jawab dengan anaknya, dia tega meninggalkan anak serta istrinya sampai berbulan-bulan tidak ada kabar juga tidak ada kiriman uang untuk biaya hidup anak dan isterinya.

Hal tersebut juga diperkuat dengan hasil wawancara dengan bapak Sujali1 ${ }^{34}$ :

"Kalau menurut saya dampak negatif pernikahan yang atas dasar paksaan biasanya dalam pernikahan tersebut pasangan suami isteri kurang bertanggung jawab atas pernikahanya, mereka bisa seenaknya saja terhadap pasanganya, dan kurang ada rasa empati terhadap pasanganya, saya juga pernah mendengar pernyataan dari seseorang, dari keluarga Bapak rokhim dan ibu anggun, bu anggun seenaknya saja sama suami tanpa ada rasa hormat, karena bu anggun berpikiran kalo dia bukan pria pilihan saya jadi saya bisa seenaknya saja sama dia."

Dari yang dikatakan oleh Bapak Sujalil pernikahan tersebut sama sekali tidak sesuai dengan apa yang ada dalam Kompilasi Hukum Islam Pasal 77 ayat (2) :suami isteri wajib saling cinta mencintai, hormat menghormati, setia dan memberi bantuan lahir bathin yang satu kepada yang lain ${ }^{35}$.

\footnotetext{
32 Kompilasi Hukum Islam, hlm. 24

${ }^{33}$ Moh. Ra'I, Tanggal 31 juli 2018.

${ }^{34}$ Hasil wawancara dengan Bapak Sujalil selaku Kaur Kesra Desa Karang Wedoro Kecamatan Turi Kabupaten Lamongan.

${ }^{35}$ Kompilasi Hukum Islam, hlm. 24
} 
c. Sering terjadi pertengkaran dalam keluarga.

Selain tidak adanya rasa kasih sayang dan rasa tanggung jawab dalam pernikahan tersebut, sering terjadi pertengkaran juga termasuk dampak dari nikah paksa, seseorang merasa semenahmenah dengan pernikahanya karena mereka mempunyai pemikiran kalau pernikahan tersebut tidak sesuai keinginanya,jadi pertengkaran merupakan hal yang biasa baginya,apabila keluarga tersebut secara terus menerus melakukan pertengkaran, maka seorang tersebut boleh untuk mengajukan perceraian dengan alasan sesuai dengan apa yang ada dalam Kompilasi Hukum Islam Pasal 116 huruf (f): antara suami dan isteri terus menerus terjadi perselisihan dan pertengkaran dan tidak ada harapan akan hidup rukun lagi dalam rumah tangga ${ }^{36}$. Berikut ini hasil wawancara dengan Bapak Juniman ${ }^{37}$ :

"dulu saya berfikir pernikahan yang dipaksakan tidak begitu banyak menimbulkan dampak negatif, semuanya berjalan dengan baik-baik saja dengan seiring berjalanya waktu, tetapi anggapan itu salah, anak saya hampir tiap hari bertengkar, rasa tanggung jawab sebagai istri sama sekali tidak ada, menantu saya selalu membangkang terhadap suaminya, dan mereka berdua akhirnya memilih jalan akhir yaitu bercerai.

Berikut salah satu pemaparan lagi dari bapak Rokhim ${ }^{38}$ :

"Saya sangat menyesal dulu mau dinikahkan secara paksa, dulu saya berpikiran kalau nurut sama orang tua pasti membawa kebaikan dalam pernikahan saya, tetapi tidak, setiap harinya saya selalu bertengkar dengan istri saya bahkan dengan mertua saya, dan akhirnya saya memilih jalan yaitu bercerai".

Dari semua hasil wawancara peneliti tidak menemukan keluarga yang harmonis dan tetap berlanjut pernikahanya, semuanya pasti berujung pada perceraian, dari pernyataan tersebut sama sekali tidak sesuai dengan apa yang ada dalam Kompilasi Hukum Islam dalam Pasal 77 tentang Hak Dan Kewajiban Suami Isteri yaitu ${ }^{39}$ :

\footnotetext{
${ }^{36}$ Kompilasi Hukum Islam, hlm. 2

37 Bapak Juniman, Tanggal 30 Juni 2018.

${ }^{38}$ Hasil wawancara dengan Bapak Rokhim Tanggal 30 Juli 2018

${ }^{39}$ Kompilasi Hukum Islam, hlm. 88
} 
(1) Suami isteri memikul kewajiban yang luhur untuk menegakkan rumah tangga yang sakinah, mawaddah dan rahmah yang menjadi sendi dasar dan susunan masyarakat.

(2) Suami isteri wajib saling mencintai, hormat menghormati, setia dan memberi bantuan lahir bathin yang satu kepada yang lain;

(3) Suami isteri memikul kewajiban untuk mengasuh dan memelihara anak-anak mereka, baik mengenai pertumbuhan jasmani, rohani maupun kecerdasannya dan pendidikan Agamanya.

(4) Suami isteri wajib memelihara kehormatannya.

(5) Jika suami atau isteri melakukan kewajibanya masing-masing dapat mengajukan gugatan kepada Pengadilan Agama.

\section{Penutup}

Ada 3 (tiga) faktor nikah paksa yang dilakukan di Desa Karang Wedoro Kecamatan Turi Kabupaten Lamongan;

a. Faktor Ekonomi

b. Faktor Pendidikan

c. Strata Sosial

Dampak negatif akibat nikah paksa adalah, pertama; tidak adanya rasa cinta dan kasih sayang. kedua; kurangnya rasa tanggung jawab terhadap keluarganya. Ketiga; sering terjadi pertengkaran dalam keluarga.

\section{Daftar Pustaka}

Undang-undang No 1 Tahun 1974 Tentang Perkawinan

KHI (Kompilasi Hukum Islam)

Abu Malik Kamal bin Ass-Sayyid Salim. Fiqih Sunnah Wanita. Jakarta: Raja

Grafindo, 2012.

Atiqah Hamid, Fiqih Wanita. Diva Press: 2016.

Erna Karim. Pendekatan Perceraian dari Prespektif Sosiologi, Dalam Ihromi,

Bunga Rampai Sosiologi Keluarga. Jakarta: Yayasan Obor Indonesia,1999.

Departemen Pendidikan Nasiona. KBBI, Jakarta: PT Gramedia Pustaka

Utama, 2008.

Rifyal Ka'bah. Permasalahan Pernikahan Dalam Majalah Varian Peradilan No.

271 juni 2008. Jakarta:IKAHI, 2008.

Sudarsono. Hukum Perkawinan Nasional. Jakarta: Rieka Cipta, 1994.

Zahri Hamid. Pokok-Pokok Hukum Pernikahan Islam dan Undang-undang Pernikahan Indonesia. Yogyakarta: Bina Cipta. 1976.
Cinta
dan
Kaih
Sayang,

CINTA.ORGANISASI.ORGBKP.BLOGSPOT.COM, 
http://cinta.organisasi.org/1970/01/efek-dampak-burukperjodohan-nikah-kawin-paksa-seperti-siti-nurbaya.html?m=1 (diakses pada: 11 november 2018).

Wawancara dengan Abdul Salam selaku Orang Tua dari pelaku Nikah Paksa sekaligus Moden Desa Karang Wedoro Kecamatan Turi Kabupaten Lamongan

Wawancara dengan Alfiyah selaku Orang Tua dari pelaku Nikah Paksa. Wawancara dengan Juniman selaku Orang Tua dari pelaku Nikah Paksa. Wawancara dengan Tutik selaku Orang Tua dari pelaku Nikah Paksa. Wawancara dengan Hariyono selaku Orang Tua dari pelaku Nikah Paksa. Wawancara dengan Sutrisno selaku Tokoh Masyarakat Desa Karang Wedoro.

Wawancara dengan Sujalil selaku Kaur Kesra Desa Karang Wedoro Kecamatan Turi Kabupaten Lamongan.

Wawancara dengan Rokhim. 